\title{
To Evaluate the Diagnostic Impact of Gastrointestinal Symptoms in Pediatric Patients with Inflammatory Bowel Disease and Polyp
}

\author{
Inflamatuvar Bağırsak Hastalığı ve Polipli Çocuk Hastalarda \\ Gastrointestinal Semptomların Tanısal Etkisini Değerlendirmek
}

Selim DERECI, Tugba KOCA, Mustafa AKCAM

Division of Pediatric Gastroenterology, Hepatology and Nutrition, Department of Pediatrics, S. Demirel University Faculty of Medicine, Isparta, Turkey

\begin{abstract}
Objective: To evaluate the diagnostic impact of gastrointestinal symptoms (GIS) in pediatric patients with inflammatory bowel disease and polyps detected by colonoscopy.

Material and Methods: Results of Colonoscopy performed on children younger than 18 years, between 2010 and 2015 in our clinic were retrospectively reviewed. All colonoscopy procedures were performed using a Fujinon EC 530LP IC657K068 video-colonoscope. Data regarding age, gender, indications, complications, and final diagnoses were collected and analyzed.

Results: One hundred and thirty-six children undergoing 121 colonoscopies and 15 sigmoidoscopies were enrolled. Seventy-five patients (55.1\%) were boys, with a mean age of $11.8 \pm 4.1$ years ( $1-18$ years). The most common indication was chronic abdominal pain (42.1\%, $n=51)$, followed by lower gastrointestinal bleeding (37.2\%, $n=45)$, and chronic diarrhea (10.8\%, n=13). Conclusive diagnosis relied on endoscopic imaging and/or histology in 75 (62\%) patients, including nonspecific colitis (23.9\%, $n=29)$, polyp (19\%, $n=23)$, inflammatory bowel disease (IBD) $(8.2 \%, n=10)$, which had normal $(38 \%, n=56)$ findings. The sensitivity of the rectal bleeding in predicting the presence of polyp was $86.9 \%$, specificity $74.49 \%$. Chronic diarrhea and iron deficiency IBD predictive sensitivities (40\%, $20 \%$, respectively) and positive predictive value $(30.77 \%, 20 \%$, respectively) was low, while specificity $(91.89 \%, 92.79 \%$, respectively) and negative predictive value $(94.44 \%, 92.79 \%$, respectively) was found to be high.

Conclusion: It is very important to diagnose according to GIS symptoms. Rectal bleeding was found to be the most sensitive symptom for polyps. Chronic diarrhea was the most specific symptom in predicting the diagnosis of IBD. In order to make the most accurate diagnosis with colonoscopy in children, GIS symptoms must be taken into consideration.

Key Words: Children, Colonoscopy, Diagnosis, Impact, Inflammatory Bowel Disease, Polyp

öz

Amaç: Kolonoskopi işlemi ile inflamatuar bağırsak hastalı̆̆ı ve polip tespit edilen çocuk hastalarda gastrointestinal semptomların (GIS) tanısal etkisini değerlendirmek.

Gereç ve Yöntemler: Kliniğimizde 2010-2015 yılları arasında 18 yaş altı çocuklara uygulanan kolonoskopi sonuçları geriye dönük olarak incelendi. Tüm kolonoskopi işlemleri Fujinon EC 530LP IC657K068 video kolonoskop kullanılarak gerçekleştirildi. Yaş, cinsiyet, endikasyonlar, komplikasyonlar ve son tanılarla ilgili veriler toplandı ve analiz edildi.
\end{abstract}

(1)
Conflict of Interest / Çıkar Çatışması: On behalf of all authors, the corresponding author states that there is no conflict of interest.

: 0000-0001-8689-3783 $0000-0002-5391-1161$ 0000-0002-4635-7630 with the decision dated 06.01.2016 and numbered 27.
Ethics Committee Approval / Etik Kurul Onayı: The study was approved by Süleyman Demirel University, Faculty of Medicine, Clinical Research Ethics Committee

Contribution of the Authors / Yazarların katkıs: DERECI S: Taking responsibility in patient follow-up, collection of relevant biological materials, data management and reporting, execution of the experiments, Taking responsibility in logical interpretation and conclusion of the results, Taking responsibility in necessary literature review for the study. Taking responsibility in the writing of the whole or important parts of the study. KOCA T: Planning methodology to reach the Conclusions, Providing personnel, environment, financial support tools that are vital for the study. AKCAM M: Constructing the hypothesis or idea of research and/or article, Organizing,

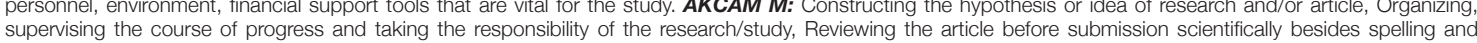
grammar.

How to cite / Atıf yazım șekli : Dereci S, Koca T, Akcam M. To Evaluate the Diagnostic Impact of Gastrointestinal Symptoms in Pediatric Patients with Inflammatory Bowel Disease and Polyp. Turkish J Pediatr Dis 2021;15:470-475.
Correspondence Address / Yazışma Adresi:
Received / Geliş tarihi : 27.09 .2020 Accepted / Kabul tarihi : 27.10.2020

Online published Elektronik yayın tarihi

DOI: 10.12956/tchd.800732 
Bulgular: Yüz otuz altı çocuğa 121 kolonoskopi ve 15 sigmoidoskopi işlemi yapıldı. Yetmiş beş hasta (\% 55.1) erkek ve yaş ortalaması $11.8 \pm 4.1 \mathrm{yıl}(1-18 \mathrm{yll}$ )'dı. En yaygın endikasyon kronik karın ağrısı (\% 42.1, $\mathrm{n}=51$ ), ardından alt gastrointestinal kanama (\% 37.2, $\mathrm{n}=45)$ ve kronik ishal (\% 10.8, n=13)'dü. Endoskopik görüntüleme ve / veya histoloji sonuçlarına göre 75 (\% 62 ) hastaya spesifik olmayan kolit (\% 23.9, n=29), polip (\% 19, n=23), enflamatuar bağırsak hastalığı (IBH) (\% 8.2, n=10) tanıları konuldu ve 56 (\%38)hasta normal olarak değerlendirildi. Rektal kanama polip varlığını öngörmede \% 86.9 duyarlı, \% 74.49 özgüldü. IBH belirlemede kronik ishal ve demir eksikliğinin duyarılıkları (sırasıyla \% 40, \% 20) ve pozitif prediktif değeri (sırasıyla \% 30.77, \% 20) düşük, özgüllüğü (sırasıyla \% 91.89, \% 92.79) ve negatif prediktif değeri (sırasıyla \%94.4, \% 92.79) yüksek bulundu.

Sonuç: Gastrointestinal semptomlar doğrultusunda tanı koymak çok önemlidir. Rektal kanama poliplerin tespitinde en hassas semptom olarak değerlendirildi. Inflamatuvar barsak hastalığı tanısını öngörmede en spesifik semptom kronik ishaldı. Çocuklarda kolonoskopi ile doğru tanı konulabilmesi için GiS semptomlarının dikkate değerlendirilmesi gereklidir.

Anahtar Sözcükler: Çocuk, Kolonoskopi, Tanı, Etki, İnflamatuar Bağırsak Hastalığı, Polip

\section{INTRODUCTION}

Colonoscopy is an important technique used in the diagnosis and treatment of gastrointestinal disease children with digestive symptoms $(1,2)$. The technique entered first into widespread use in adults and was employed in the pediatric age group at year of 1970. Significant advances have been made, thanks to new fiber optic devices and video techniques in pediatric colonoscopic practice and increasing experience on the part of physicians (3-5).

Pediatric colonoscopy is generally employed in the diagnosis and treatment of recurring abdominal pain, lower gastrointestinal bleeding, chronic diarrhea, polyp and inflammatory bowel diseases (IBD) (1-6). Biopsies were taken during the procedure which also permits the diagnosis of diseases detectable at the microscopic level, such as eosinophilic colitis (4). Studies have shown that colonoscopy with appropriate safety precautions, an experienced team, and suitable equipment is an effective and safe technique (4,7-9).

We aimed to evaluate the diagnostic impact of gastrointestinal system symptoms in pediatric patient with IBD and polyp who undergone the colonoscopy procedure.

\section{MATERIALS and METHODS}

This study was performed as a retrospective evaluation of colonoscopy results from the Pediatric Gastroenterology Department of $\mathrm{S}$. Demirel University, a tertiary hospital in the southwest of Turkey. Data for children younger than 18 years undergoing colonoscopy between January 2010 and December 2015 were accessed from the patient file archive system. Children's demographic characteristics, colonoscopy indications, results and diagnoses were analyzed. Our institution was the only center that provided a pediatric colonoscopy service in the region.

All of the colonoscopy procedures were performed by two pediatric gastrointestinal endoscopists using a Fujinon EC 530LP IC657K068 colonoscope. All patients were advised to consume a pulp-free diet (pulp-free soup, pulp-free stewed fruit, tea, fruit juice, yoghurt, etc.) for 2 days before the procedure for purposes of colon cleansing. On the evening before the procedure, they were recommended to drink oral sodium phosphate (drug dose: 5-9 years, 5-10 ml; 10-11 years, 10-20 ml and over 12 years, 20-45 ml), and the use of liquid enemas containing sodium phosphate was advised. Enemas were repeated prior to the procedure. During the procedure, all patients were given midazolam $0.1 \mathrm{mg} / \mathrm{kg}$ followed by ketamine $1 \mathrm{mg} / \mathrm{kg}$ intravenously for sedation. Children were monitored using pulse oximetry during and for $2 \mathrm{~h}$ after the procedure. The procedure was performed with the patients lying on their left sides. Biopsies were taken from all areas in which pathological lesions were observed, and sometimes also from normal areas for diagnostic purposes. If a polyp was found, removed using by polypectomy, and the specimen was sent for histologic studies. Specimens were sent to the pathology laboratory for examination. Pathological examination was performed by an experienced pathologist. Patients were diagnosed by colonoscopy and/or pathology laboratory results.

The study was approved by Süleyman Demirel University, Faculty of Medicine, Clinical Research Ethics Committee with the decision dated 06.01.2016 and numbered 27.

\section{Statistical Analysis}

The statistical analysis was performed using the Statistical Package for the Social Sciences version (SPSS, Inc., Chicago, IL, USA). The data were assessed using the complementarydescriptive statistical method. The categorical variables were expressed as percentage (\%) values.

Sensitivity, specificity, positive predictive value (PPV), negative predictive value (NPV), positive likelihood ratio $(+L R)$ and negative likelihood ratio (-LR) values were calculated to determine the effects of symptoms on the prediction of polyp and IBD.

\section{RESULTS}

One hundred and thirty-six procedures were performed in the study period. One hundred and twenty-one patients with 121 colonoscopies and 15 rectosigmoidoscopies were enrolled. 
Table I: Demographic data of the patients undergoing colonoscopy.

\begin{tabular}{l|c}
\hline & No (\%) \\
\hline Total procedures & 136 \\
Colonoscopy & $121(89 \%)$ \\
Rectosigmoidoscopy & $15(11 \%)$ \\
Total first procedures & 121 \\
Colonoscopy & $109(90 \%)$ \\
Rectosigmoidoscopy & $12(10 \%)$ \\
Male:female & $75(55.1 \%): 61(44.9 \%)$ \\
Age (years) & $11.8 \pm 4.1$ \\
Examination times (minutes) & $21.7 \pm 8.4$ \\
Biopsy & $86(\% 63)$ \\
\hline
\end{tabular}

Table II: Indications for colonoscopy or sigmoidoscopy and the diagnostic yields.

\begin{tabular}{|c|c|c|c|}
\hline Indications & Patient no. (\%) & Diagnostic yield & Patient no. (\%) \\
\hline Chronic abdominal pain & $51(42.1)$ & $\begin{array}{l}\text { Nonspecific colitis } \\
\text { Polyp(s) } \\
\text { IBD } \\
\text { Others* } \\
\text { Negative }\end{array}$ & $\begin{array}{c}21(17.4) \\
3(2.5) \\
2(1.6) \\
4(3.3) \\
21(17.4)\end{array}$ \\
\hline Lower gastrointestinal bleeding & $45(37.2)$ & $\begin{array}{l}\text { Polyp(s) } \\
\text { IBD } \\
\text { Others* } \\
\text { Nonspecific colitis } \\
\text { Negative }\end{array}$ & $\begin{aligned} & 20(16.5) \\
& 2(1.6) \\
& 4(3.3) \\
& 2(1.6) \\
& 17(14)\end{aligned}$ \\
\hline Chronic diarrhea & $13(10.8)$ & $\begin{array}{l}\text { Nonspecific colitis } \\
\text { IBD } \\
\text { Other* } \\
\text { Negative }\end{array}$ & $\begin{array}{l}6(5) \\
4(3.3) \\
2(1.6) \\
1(0.8)\end{array}$ \\
\hline Iron deficiency anemia & $10(8.3)$ & $\begin{array}{l}\text { IBD } \\
\text { Others* } \\
\text { Negative }\end{array}$ & $\begin{array}{l}2(1.6) \\
3(2.5) \\
5(4.1)\end{array}$ \\
\hline Body weight loss & $1(0.8)$ & Negative & $1(0.8)$ \\
\hline Intestinal gas & $1(0.8)$ & Negative & $1(0.8)$ \\
\hline
\end{tabular}

*Others: Enterobius vermicularis, hemangioma, hemorrohoids, and proctitis; IBD: Inflamatory bowel disease.

Fifteen (11\%) children underwent more than one procedure. Seventy-five (55.1\%) children were male and 61 (44.9\%) female, with a mean age of $11.8 \pm 4.1$ years $(1-18)$.

Symptoms among children undergoing colonoscopy were, in order of prevalence, chronic abdominal pain in 51 (42.1\%), lower digestive system bleeding in $45(37.2 \%)$, chronic diarrhea in $13(10.8 \%)$, iron deficiency anemia in 10 (8.3\%), weight loss in $1(0.8 \%)$ and excessive flatulence in $1(0.8 \%)$.

Anatomical areas accessed during all procedures were the cecum in 68 (50\%) patients, the terminal ileum in 66 (48\%) and other colonic regions. Mean duration of the procedure was $21.7 \pm 8.4(5-39)$ min. biopsy specimens were taken from 86 children (63\%) (Table I).

Diagnoses based on colonoscopy and biopsy specimens investigated in the pathology laboratory were nonspecific colitis in 29 (23.9\%) patients, polyp in 23 (19\%), IBD in 10 (8.3\%) and others in 13 (10.7\%) (Table II). The group defined as 'other diagnoses' included Enterobius vermicularis (2), hemangioma (5), hemorrhoids (1), and proctitis (5). Nonspecific colitis was the most common diagnosis, and these cases were placed under clinical observation. The diagnosis was made in 75 (62\%) cases. No pathology was determined at colonoscopy in the remaining $46(38 \%)$ children.

The two main symptoms in the 23 patients with polyp were lower digestive system bleeding and chronic abdominal pain. Polyps were most commonly located in the rectum, at 82\% (19/23), but also in other areas (cecum: 2, sigmoid: 1 , ascending colon: 1, descending colon: 1, transverse colon: 1). With the exception of two patients, polyps were single. Multiple polyps were detected in the rectum in one of these patients and diffuse polyps along the colonic segments in the other. All polyps observed were removed using polypectomy device. 
Table III: Statistical analysis of polyp symptoms.

\begin{tabular}{|l|c|c|c|c|c|c|}
\hline & Sensitivity (\%) & Specificity (\%) & PPV (\%) & NPV (\%) & +LR (\%) & -LR (\%) \\
\hline Abdominal pain & 13.04 & 51.02 & 70.58 & 71.43 & 0.27 & 1.70 \\
\hline Bleeding & 86.96 & 74.49 & 44.44 & 96.05 & 3.41 & 0.18 \\
\hline Diarrhea & 0 & 86.73 & 0 & 78.70 & 0 & 1.15 \\
\hline Iron deficiency & 0 & 89.79 & 0 & 79.28 & 0 & 1.11 \\
\hline Weight loss & 0 & 1.02 & 0 & 80.83 & 0 & 1.01 \\
\hline Intestinal gas & 0 & 1.02 & 0 & 80.83 & 0 & 1.01 \\
\hline
\end{tabular}

PPV: Positive predictive value, NPV: Negative predictive value, +LR: Positive likelihood ratio, - LR: negative likelihood ratio

Table IV: Statistical analysis of inflammatory bowel disease symptoms.

\begin{tabular}{l|c|c|c|c|c|c}
\hline & Sensitivity (\%) & Specificity (\%) & PPV (\%) & NPV (\%) & +LR (\%) & -LR (\%) \\
\hline Abdominal pain & 20.00 & 55.86 & 3.92 & 88.57 & 0.45 & 1.43 \\
\hline Bleeding & 30.00 & 62.16 & 6.67 & 90.79 & 0.79 & 1.13 \\
\hline Diarrhea & 40.00 & 91.89 & 30.77 & 94.44 & 3.70 & 0.76 \\
\hline Iron deficiency & 20.00 & 92.79 & 20.00 & 92.79 & 2.78 & 0.86 \\
\hline Weight loss & 10.00 & 100.00 & 100.00 & 92.50 & 0.00 & 0.90 \\
\hline Intestinal gas & 10.00 & 100.00 & 100.00 & 92.50 & 0.00 & 0.90 \\
\hline
\end{tabular}

PPV: Positive predictive value; NPV: Negative predictive value; +LR:Positive likelihood ratio; $-\mathbf{L R}$ : Negative likelihood ratio

Symptoms on arrival in the 10 patients diagnosed with IBD were chronic diarrhea (4), chronic abdominal pain (2), lower digestive system bleeding (2) and iron deficiency anemia (2). Ulcerative colitis was diagnosed in eight of these patients and Crohn's disease in the other two.

Although rectal bleeding was the most common symptom in colonoscopy, there was no difference in rectal bleeding between patients with polyps and patients without polyps $(\mathrm{P}=0.456)$. The sensitivity of the rectal bleeding in predicting the presence of polyp was $86.9 \%$, specificity $74.49 \%$, PPV $44.44 \%$, NPV $96.05 \%$, + LR 3.41\%, - LR 0.18\%. While abdominal pain was less common in children who had polyps $(P<0.001)$, the sensitivity of abdominal pain in predicting polyps was $13.04 \%$, specificity was $51.02 \%$, PPV $70.58 \%$, NPV $71.43 \%$, LR $0.27 \%$, -LR 1.70\% (Table III).

Although chronic diarrhea and iron deficiency were common in patients with IBD, no statistically significant difference was found between patients without IBD $(P=0.166, P=0.058$, respectively). Chronic diarrhea and iron deficiency $\mathrm{IBH}$ predictive sensitivities (40\%, 20\%, respectively) and PPV (30.77\%, 20\%, respectively) were low, while specificity $(91.89 \%, 92.79 \%$, respectively) and NPV (94.44\%, 92.79\%, respectively) was found to be high (Table IV).

Abdominal pain and GIS bleeding were less frequent in IBD ( $P$ $<0.001)$. While specificity and sensitivity of abdominal pain and GIS bleeding were low in IBD prediction, NPV values were high (88.57\%, 90.79\%, respectively).

\section{DISCUSSION}

The colonoscopic examination is becoming increasingly used in the pediatric age group (1-6). However, due to pre-procedural preparation, sedation and other difficulties concerning the procedure specific to children, its use is more limited than in adults (10). However, pediatric colonoscopy is safely performed in many tertiary health centers, including on newborn babies, with experienced gastroenterology specialists and appropriate equipment (1-4).

Indications for pediatric colonoscopy in a 14-center study from America evaluating 21,800 children, were listed as abdominal pain (40.19\%), lower digestive system bleeding (32.1\%), diarrhea (27\%), IBD (21\%) and weight loss (11.6\%) (1). In a study of 79 children from Hong Kong, the most common indications were rectal bleeding (58\%) and suspected IBD (29.1\%) (5). In a study of 192 children from Taiwan, by Wu et al. (3), indications were listed as lower digestive system bleeding (53.5), chronic abdominal pain (20.6\%), iron deficiency anemia (11.8\%), chronic diarrhea (10.8\%) and weight loss (0.8\%). Similarly to those of the multicenter study, our findings were chronic abdominal pain (42.1\%), lower digestive system bleeding (37.2\%), diarrhea (11\%) and weight loss $(0.8 \%)$. The indication of iron deficiency anemia was not mentioned in that multicenter study (1). Our finding is similar to the Taiwanese study.

Diagnosis of children undergoing colonoscopy is made through endoscopic or histological investigation (1-5). Wu et al. (3) established diagnosis at a level of $75 \%$ following the procedures and Tam et al.(5) at a level of 50.6\%. In our study, the diagnosis 
was established in $62 \%$ of children undergoing colonoscopy and/or histological investigation. We attribute the difference between levels of diagnosis to causes such as colonoscopy indications and regional differences.

The diagnoses made and the prevalence of these varies between published studies. Nonetheless, the most common diagnoses are nonspecific colitis, polyp and IBD $(1,3,7,11,14)$. Nonspecific colitis was the most common diagnosis in our study, at $23.9 \%$. This finding is compatible with Wu et al.(3) study (23.4\%).

The second most common diagnosis in our study was polyp (19\%). Levels of $20.4 \%$ and $29.1 \%$ have been reported in studies from Taiwan and China $(3,5)$. De Ridder et al. (11) diagnosed Crohn's disease in $72 \%$ and polyp in $22 \%$ of 137 Dutch children undergoing colonoscopy due to rectal bleeding. Although only children undergoing colonoscopy due to rectal bleeding were investigated in that study, polyp levels were similar.

In our study, polyps were mainly observed in the rectum (82\%). Our results are similar to findings from Holland (11) and India (15). The sensitivity of rectal bleeding was high in predicting polyps, its specificity was relatively low, but NPV was high. The prevalence of polyp detection during pediatric colonoscopy is higher in Asian societies (20.3-20.5\%) than in Western ones $(4.0-8.6 \%)(5,11-14)$. Polyps have been detected in the rectal region at levels of $80-90 \%$ in several reports $(15,16)$. Fifty-four percent of polyps have been observed in the recto sigmoid region in results from North America (17).

The prevalence of IBD, the third most common diagnosis in our study, has increased in developed countries in recent years (18-20). The annual prevalence of IBD in Great Britain and America is estimated at 5.2-7.04 in $100.000(21,22)$. Studies have attributed this increase in pediatric IBD to changes in environmental factors (5). In the Taiwan study, the level of IBD was $8.3 \%$ in children undergoing colonoscopy for all indications (3). In our study, IBD was determined at a level of $8.2 \%$ based on colonoscopies performed for all indications.

In de Ritter et al. (11) study from Holland, $72 \%$ of children presenting with rectal bleeding were diagnosed with Crohn's disease. In another pediatric colonoscopy study of 999 children, rectal bleeding was reported as $20 \%$ (23). We diagnosed IBD in only $20 \%$ of children presenting due to rectal bleeding. With these findings, our IBD levels are lower than those from Europe and close to those from Asia. Gastrointestinal bleeding was not a sensitive and specific symptom in predicting the disease; NPV was high in patients with IBD. Chronic diarrhea was the most common complaint in our patients with IBD. Although the sensitivity of chronic diarrhea and iron deficiency in the prediction of IBD was low, specificity and NPV values were found to be high.

\section{CONCLUSION}

Colonoscopy is of considerable diagnostic and/or therapeutic importance in children presenting with such symptoms as lower digestive system bleeding, unexplained chronic abdominal pain and chronic diarrhea, as in other studies. Rectal bleeding was found to be the most sensitive symptom for diagnosis of polyps. Chronic diarrhea was most specific symptom in predicting the diagnosis of IBD. In order to make the most accurate diagnosis with colonoscopy in children, GIS symptoms must be taken into consideration.

\section{REFERENCES}

1. Thakkar K, Holub JL, Gilger MA, Shub MD, McOmber M, Tsou M, et al. DS.Quality indicators for pediatric colonoscopy: results from a multicenter consortium. Gastrointest Endosc 2016; 83:533-41.

2. Park JH. Pediatric Colonoscopy: The Changing Patterns and Single Institutional Experience Over a Decade. Clin Endosc 2018;51:13741.

3. Wu CT, Chen CA, Yang YJ. Characteristics and Diagnostic Yield of Pediatric Colonoscopy in Taiwan. Pediatr Neonatol 2015; 56:3348.

4. Jae Hong Park. Role of colonoscopy in the diagnosis and treatmentof pediatric lower gastrointestinal disorders. Korean J Pediatr 2010; 53:824-9.

5. Tam YH, Lee KH, Chan KW, Sihoe JD, Cheung ST, Mou JW. Colonoscopy in Hong Kong Chinese children. World J Gastroenterol 2010;16: 1119-92.

6. Wahid AM, Devarajan K, Ross A, Zilbauer M, Heuschkel R. Paediatric gastrointestinal endoscopy: a qualitative study. Eur J Gastroenterol Hepatol 2016;28:25-9.

7. Victor LF. Colonoscopy. In: Walker WA, Durie PR, Hamilton JR, Walker-Smith JA, Watkins JB (eds). Pediatric gastrointestinal disease. Pathophysiology, diagnosis, management. 2nd ed. St. Louis: Mosby, 1996;1533-41.

8. Thomson M. Colonoscopy and enteroscopy. Gastrointest Endosc Clin N Am 2001; 11:603-39.

9. Dahshan A, Lin CH, Peters J, Thomas R, Tolia V. A randomized, prospective study to evaluate the efficacy and acceptance of three bowel preparations for colonoscopy in children. Am J Gastroenterol 1999;94:3497-01.

10. Gilger MA, Gold BD. Pediatric endoscopy: new information from the PEDS-CORI project. Curr Gastroenterol Rep 2005;7:234-9.

11. de Ridder L, van Lingen AV, Taminiau JA, Benninga MA. Rectal bleeding in children: endoscopic evaluation revisited. Eur J Gastroenterol Hepatol 2007;19:317-20.

12. Tam PK, Saing H. Pediatric surgeons can and should perform colonoscopy. J Pediatr Surg 1987;22:332-4.

13. Lindberg E, Lindquist $B$, Holmquist L, Hildebrand H. Inflammatory bowel disease in children and adolescents in Sweden, 1984-1995. J Pediatr Gastroenterol Nutr 2000;30:259-64.

14. Bowles CJ, Leicester R, Romaya C, Swarbrick E, Williams CB, Epstein $\mathrm{O}$. A prospective study of colonoscopy practice in the UK today: are we adequately prepared for national colorectal cancer screening tomorrow? Gut 2004;53:277-83. 
15. Poddar U, Thapa BR, Vaiphei K, Singh K. Colonic polyps: experience of 236 Indian children. Am J Gastroenterol 1998;93:619-22.

16. Jalihal A, Misra SP, Arvind AS, Singh K. Colonoscopic polypectomy in children. J Pediatr Surg 1992;27:1220-2.

17. Gupta SK, Fitzgerald JF, Croffie JM, Chong SK, Pfefferkorn MC, Davis MM, et al. Experience with juvenile polyps in North American children: the need for pancolonoscopy. Am J Gastroenterol 2001;96:1695-7.

18. Barton JR, Gillon S, Ferguson A. Incidence of inflammatory bowel disease in Scottish children between 1968 and 1983; marginal fall in ulcerative colitis, three-fold rise in Crohn's disease. Gut 1989;30:618-22.

19. Armitage E, Drummond H, Ghosh S, Ferguson A. Incidence of juvenile-onset Crohn's disease in Scotland. Lancet 1999;353:14967.
20. Cosgrove M, Al-Atia RF, Jenkins HR. The epidemiology of paediatric inflammatory bowel disease. Arch Dis Child 1996;74:460-1.

21. Sawczenko A, Sandhu BK, Logan RF, Jenkins H, Taylor CJ, Mian $S$, et al. Prospective survey of childhood inflammatory bowel disease in the British Isles. Lancet 2001; 357:1093-4.

22. Kugathasan S, Judd RH, Hoffmann RG, Heikenen J, Telega G, Khan F, et al. Epidemiologic and clinical characteristics of children with newly diagnosed inflammatory bowel disease in Wisconsin: a statewide population-based study. J Pediatr 2003;143:525-31.

23. Peytremann-Bridevaux I, Arditi C, Froehlich F, O'Malley J, Fairclough P, Le Moine O, et al. Appropriateness of colonoscopy in Europe (EPAGE II). Iron-deficiency anemia and hematochezia. Endoscopy 2009;4:227-33. 